\title{
Isolated major aortopulmonary collateral artery in an infant presenting with recurrent lower respiratory tract infection
}

\author{
Soumya Patra, Sunil Kumar Srinivas, Navin Agrawal, M Jayaranganath
}

Department of Cardiology, Sri Jayadeva Institute of Cardiovascular Sciences \& Research, Bangalore, Karnataka, India

\section{Correspondence to}

Dr Navin Agrawal, drnavinagrawal@gmail.com

\section{DESCRIPTION}

A 5-month-old baby, weighing $4 \mathrm{~kg}$ presented with a 3-month history of failure to thrive and recurrent lower respiratory tract infection (RTI). She was delivered at term weighing $2.8 \mathrm{~kg}$ and the perinatal period was uneventful. Saturation and clinical examination was normal and there were no abnormal auscultation findings or murmur. Chest $\mathrm{x}$-ray had normal cardiac and pulmonary contours while previous $\mathrm{x}$-rays had evidence of lower RTI involving the right lung. An echocardiogram showed no evidence of congenital heart disease (CHD) with no shunts and there was no evidence of left ventricular volume overload (figure 1A, B) but a colour Doppler examination showed the presence of major aortopulmonary collateral arteries (MAPCA; figure $2 \mathrm{~A}, \mathrm{~B})$. Aortic angiogram revealed an abnormal vessel arising from the descending aorta coursing towards right lung. Other findings of the pulmonary angiogram were normal with normal pulmonary arteries (figure 3A, B) and normal systemic and pulmonary venous drainage. The MAPCA was incriminated as the cause of recurrent lower respiratory tract infection as there was no other obvious explanation.

Despite an initial dilemma regarding whether to take the child for a procedure it was decided to manage her conservatively with diuretics, which is the therapy of choice in all cases of large left to right shunts after having controlled the infection with parenteral antibiotics with coil embolisation later, if required. The child improved with antibiotic therapy and was continued on medical management and close follow-up.

MAPCA are seen in cyanotic CHDs (CCHDs) which decreases pulmonary blood flow and serves as an additive or the only source of blood supply. These are commonly seen in tetralogy of Fallot and

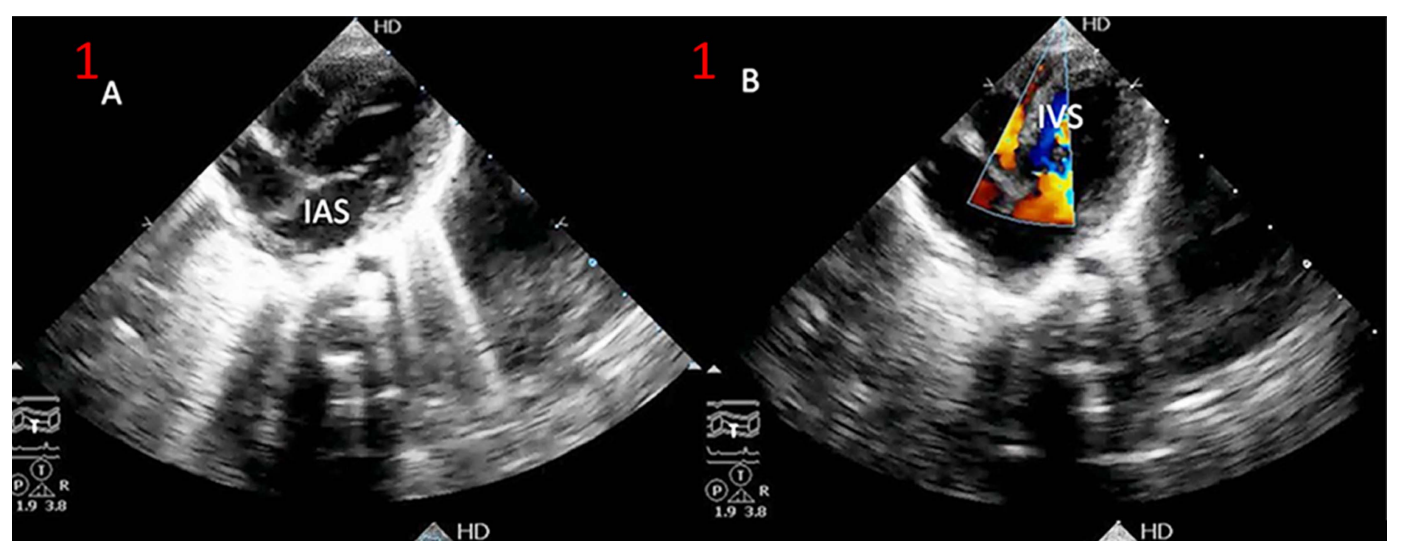

Figure 1 (A and B) Subcostal echocardiography revealing intact inter-atrial septum and inter-ventricular septum.

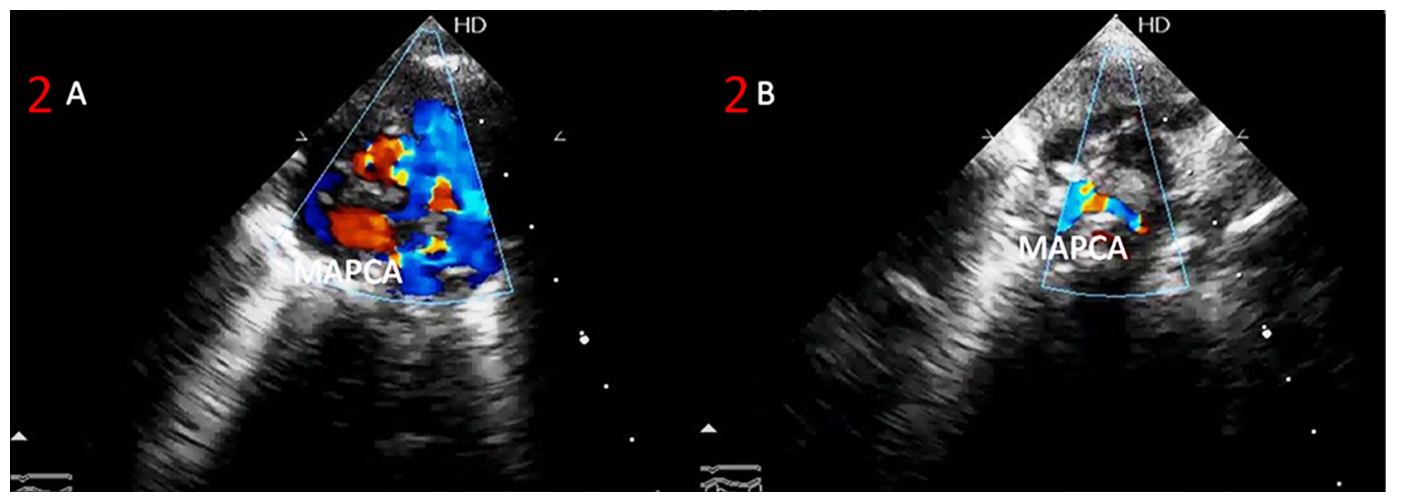

Figure 2 (A) Parasternal short axis and (B) suprasternal view demonstrating major aortopulmonary collateral arteries. 

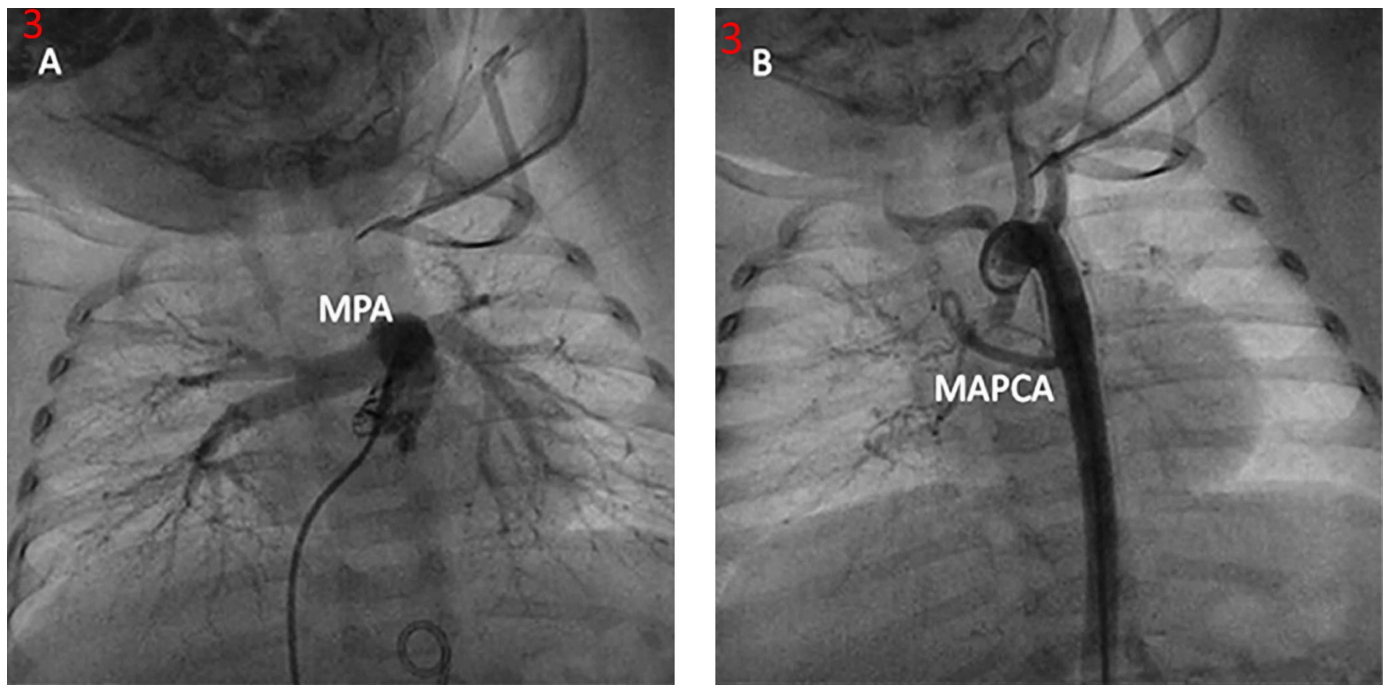

Figure 3 (A) Pulmonary angiogram revealing normal distribution of pulmonary arteries with the presence of major aortopulmonary collateral arteries (MAPCA) arising from descending aorta towards right lung. (B) Aortic angiogram revealing the origin and course of MAPCA.

similar physiology with or without pulmonary atresia. Sometimes, MAPCAs are also seen in premature neonates having bronchopulmonary disorder, though these are usually small and are rarely symptomatic. MAPCAs in the absence of CCHD usually regress spontaneously rarely requiring intervention. ${ }^{1-3}$ In our case, the baby had an isolated MAPCA which caused symptoms of recurrent chest infection.

\section{Learning points}

- Isolated major aortopulmonary collateral arteries are sometimes seen in premature neonates with bronchopulmonary disorder, but they are rare in healthy term neonates without congenital heart disease.

- Sometimes they may present with complications due to increased pulmonary blood flow.

- Symptoms if not controlled by conservative treatment with diuretics may be managed by elective coil embolisation and rarely might require surgical intervention.
Competing interests None.

Patient consent Obtained.

Provenance and peer review Not commissioned; externally peer reviewed.

\section{REFERENCES}

1 Padhi SS, Bakshi KD, Shastri RK. Multiple coil closure of isolated aortopulmonary collateral. Ann Pediatr Cardiol 2010;3:65-7.

2 Acherman RJ, Siassi B, Pratti-Madrid G, et al. Systemic to pulmonary collaterals in very low birth weight infants: colour Doppler detection of systemic to pulmonary connections during neonatal and early infancy period. Pediatrics 2000;105:528-32.

3 Holzer R, Ladusans E, Malaiya N. Aorto-pulmonary collateral arteries in a child with trisomy 21. Cardiol Young 2002;12:75-7.

Copyright 2013 BMJ Publishing Group. All rights reserved. For permission to reuse any of this content visit http://group.bmi.com/group/rights-licensing/permissions.

BMJ Case Report Fellows may re-use this article for personal use and teaching without any further permission.

Become a Fellow of BMJ Case Reports today and you can:

- Submit as many cases as you like

- Enjoy fast sympathetic peer review and rapid publication of accepted articles

- Access all the published articles

- Re-use any of the published material for personal use and teaching without further permission

For information on Institutional Fellowships contact consortiasales@bmjgroup.com

Visit casereports.bmj.com for more articles like this and to become a Fellow 